\title{
POTENSI KEPARIWISATAAN DI PULAU KARAKELONG, SULAWESI UTARA
}

\section{TOURISM POTENTIAL IN THE ISLAND OF KARAKELONG, NORTH SULAWESI}

\author{
Vita \\ Puslitbang Arkeologi Nasional \\ vitamattori@yahoo.co.id
}

\begin{abstract}
Karakelong island located in the Talaud Islands, North Sulawesi Province. In astronomy Talaud Islands lies between $3^{\circ} 45^{\prime}-5^{\circ}$ north latitude and between $126^{\circ} 30^{\prime}$ $126^{\circ} 45^{\prime}$ east longitude. The island is surrounded by natural beauty of the sea coast and forests. Archaeological remnants from this island among others are a series of Karakelong caves, one of which is the Balangingi cave. From this site has been obtained more than 2.604 fragments of pottery, three red-glass beads and two green-glass beads, two fragments of bronze/copper and a segment of bronze/copper bracelets. Radio carbon dating on charchoal samples found at the depth of $20-30 \mathrm{~cm}$ showed the date of $950 \pm 130 \mathrm{BP}$ in the middle layer of the culture. (Tanudirjo 2001). From observations made on the vegetation environment in Karakelong island, in particular in the sub distrct of Rainis (Rainis village), the physiognomy of plants can be divided in to the environment of coastal vegetation, plantation environment, bush and jungle environments. This site could be expected to be come a tourist destination in the future, considering the site has the potential for archaeological remains as well as its potential environment
\end{abstract}

Keywords: Ecotourism, Balangingi Cave, Vegetation Environment

\begin{abstract}
ABSTRAK
Pulau Karakelong terletak di Kepulauan Talaud, Provinsi Sulawesi Utara. Secara astronomi wilayah Kepulauan Talaud terletak antara $3^{\circ} 45^{\prime}-5^{\circ}$ Lintang Utara dan antara $126^{\circ} 30^{\prime}-126^{\circ} 45^{\prime}$ Bujur Timur. Pulau ini dikelilingi lautan dengan keindahan alam berupa pantai dan hutan. Data arkeologi yang tedapat di Pulau Karakelong ini berupa gua-gua hunian yang salah satunya yaitu Situs Gua Balangingi. Di situs ini telah didapatkan lebih dari 2604 pecahan gerabah, tiga manik-manik kaca berwarna merah, dan dua manikmanik kaca berwarna hijau, dua fragmen perunggu / tembaga, dan segmen gelang dari tembaga /perunggu. Dari sampel arang yang ditemukan pada kedalaman $20-30 \mathrm{~cm}$ telah dapat ditentukan umur pertanggalan C14 nya sekitar $950 \pm 130$ BP pada lapisan budaya bagian tengah (Tanudirjo, 2001). Dari pengamatan yang dilakukan terhadap lingkungan vegetasi di pulau Karakelong, khususnya Kecamatan Rainis (Desa Rainis) maka, secara fisiognomi lingkungan tumbuhan dapat dibagi atas: lingkungan vegetasi pantai, lingkungan vegetasi tanaman perkebunan, lingkungan vegetasi semak belukar, dan lingkungan vegetasi hutan. Jika dilihat dari baik data kearkeologian maupun keadaan lingkungan di situs ini maka sangat diharapkan daerah ini dapat menjadi daerah tujuan wisata di masa mendatang
\end{abstract}

Kata kunci: Ekowisata, Gua Balangingi, Lingkungan Vegetasi 


\section{PENDAHULUAN}

Perkembangan dunia pariwisata telah mengalami berbagai perubahan baik perubahan pola, bentuk dan sifat kegiatan, serta dorongan orang untuk melakukan perjalanan, cara berpikir, maupun sifat perkembangan itu sendiri.(Gamal, 1997), sedangkan menurut Salah (1976), pariwisata merupakan industri gaya baru yang mampu menyediakan pertumbuhan ekonomi yang cepat dalam hal kesempatan kerja, pendapatan, taraf hidup dan dalam mengaktifkan sektor lain di dalam negara penerima wisatawan. Di samping itu pariwisata sebagai suatu sektor yang kompleks meliputi industri-industri seperti industri kerajinan tangan, industri cinderamata, penginapan dan transportasi. Sebagai industri jasa yang digolongkan sebagai industri ketiga, pariwisata cukup berperan penting dalam menetapkan kebijaksanaan mengenai kesempatan kerja, dengan alasan semakin mendesaknya tuntutan akan kesempatan kerja yang tetap sehubungan dengan selalu meningkatnya wisata di masa yang akan datang.(James, 1993).

Ekowisatapun (ecotourism) kini telah menjadi tren global dan menjadi perhatian banyak negara. Di Indonesia walaupun belum berkembang luas, namun ekowisata telah menjadi salah satu agenda penting bagi pengembangan pariwisata Indonesia ke depan. Oleh karena itu, segenap pihak seperti industri dan pelaku pariwisata, masyarakat dan semua pihak terkait diharapkan mulai memberi perhatian lebih nyata. Sebuah kenyataan dan patut kita syukuri adalah bahwa Indonesia termasuk salah satu negara yang memiliki destinasi ekowisata terbaik di dunia. Hal ini disebabkan karena Ekowisata Indonesia bertujuan untuk mewujudkan penyelenggaraan wisata yang bertanggung jawab, yang mendukung upaya-upaya pelestarian lingkungan alam, peninggalan sejarah dan budaya; meningkatkan partisipasi masyararakat dan memberikan manfaat ekonomi kepada masyarakat setempat; dan menjadi model bagi pengembangan pariwisata lainnya, melalui penerapan kaidah-kaidah ekowisata.

Secara konsep, ekowisata adalah sebuah model pariwisata yang berwawasan dan ramah lingkungan dan sekaligus berbasiskan budaya setempat (local cultures based), serta secara langsung memberikan dampak keuntungan secara ekonomi kepada masyarakat. Model pariwisata ini menjadi ideal karena berfungsi ganda, selain sebagai objek wisata yang berbasiskan alam dan budaya setempat, ekowisata juga berfungsi sebagai konservasi, observasi, serta sarana pendidikan.

Ekowisata merupakan konsep pengembangan pariwisata yang berkelanjutan yang bertujuan untuk mendukung upaya-upaya pelestarian lingkungan (alam dan budaya) dan meningkatkan partisipasi masyarakat dalam pengelolaan, sehingga memberikan manfaat ekonomi kepada masyarakat dan pemerintah setempat.

Ekowisata memberikan peluang yang sangat besar, untuk mempromosikan pelestarian keaneka-ragaman hayati Indonesia baik di tingkat internasional, nasional, regional maupun lokal. Beberapa unsur utama untuk menetapkan visi ekowisata antara lain:

1. Kualitas sumber daya alam, peninggalan sejarah dan budaya, kekayaan keanekaragaman hayati merupakan daya tarik utama bagi pangsapasar ekowisata, sehingga kualitas, keberlanjutan dan pelestarian sumber daya alam, peninggalan sejarah dan budaya menjadi sangat penting untuk ekowisata. Pengembangan ekowisata juga memberikan peluang yang sangat besar, untuk mempromosikan pelestarian keaneka-ragaman hayati Indonesia di tingkat internasional, nasional, regional dan lokal.

2. Peran masyarakat di sekitarnya, karena pada dasarnya masyarakat setempat mempunyai pengetahuan tentang alam dan budaya kawasan daya tarik wisata. Oleh karena itu peran serta masyarakat sangat diperlukan mulai dari perencanaan hingga pada tingkat pengelolaan

3. Ekowisata dapat meningkatkan kesadaran dan apresiasi terhadap alam, nilainilai peninggalan sejarah dan budaya sehingga dapat mempengaruhi perubahan 
perilaku pengunjung, masyarakat dan pengembang pariwisata agar sadar dan lebih menghargai alam, nilai-nilai peninggalan sejarah dan budaya

4. Menumbuhkan pasar ekowisata di tingkat internasional dan nasional

5. Sebagai sarana untuk mewujudkan ekonomi berkelanjutan.

Indonesia memiliki potensi sumber daya alam dan peninggalan sejarah, seni dan budaya yang sangat besar sebagai daya tarik pariwisata dunia. Sebagai negara yang terletak di wilayah tropis, Indonesia mempunyai keanekaragaman jenis baik flora maupun fauna yang banyak tersebar di seluruh pulau-pulau di Indonesia. Sekitar 59\% dari luas daratan Indonesia merupakan hutan hujan tropis atau sekitar $10 \%$ dari luas hutan yang ada di dunia. Sekitar 100 juta hektar di antaranya diklasifikasikan sebagai hutan lindung, yang 18,7 juta hektarnya telah ditetapkan sebagai kawasan konservasi.

Pulau Karakelong berada di Kepulauan Talaud, Provinsi Sulawesi Utara. Kepulauan Talaud ini terdiri dari pulau-pulau besar dan kecil yang berjumlah sekitar 20 pulau. Pulau yang paling besar adalah Pulau Karakelong yag merupakan pusat pemerintahan dan ekonomi di Kepulauan Talaud, luasnya sekitar 200 km2, pulau kedua terbesar adalah Pulau Salibabu dan yang ketiga adalah Pulau Kabaruan yang semuanya terletak di selatan Pulau Karakelong dan sisanya adalah pulau-pulau kecil di sekitar Pulau Karakelong. Kosentrasi penduduk terdapat paling banyak di Pulau Karakelong dan Salibabu. Tidak semua pulau dihuni, pemukiman penduduk hanya terdapat di beberapa pulau kecil, seperti beberapa pulau di gugusan pulau-pulau Nanusa, Kawio dan Pulau Miangas (Thufail, 1993).

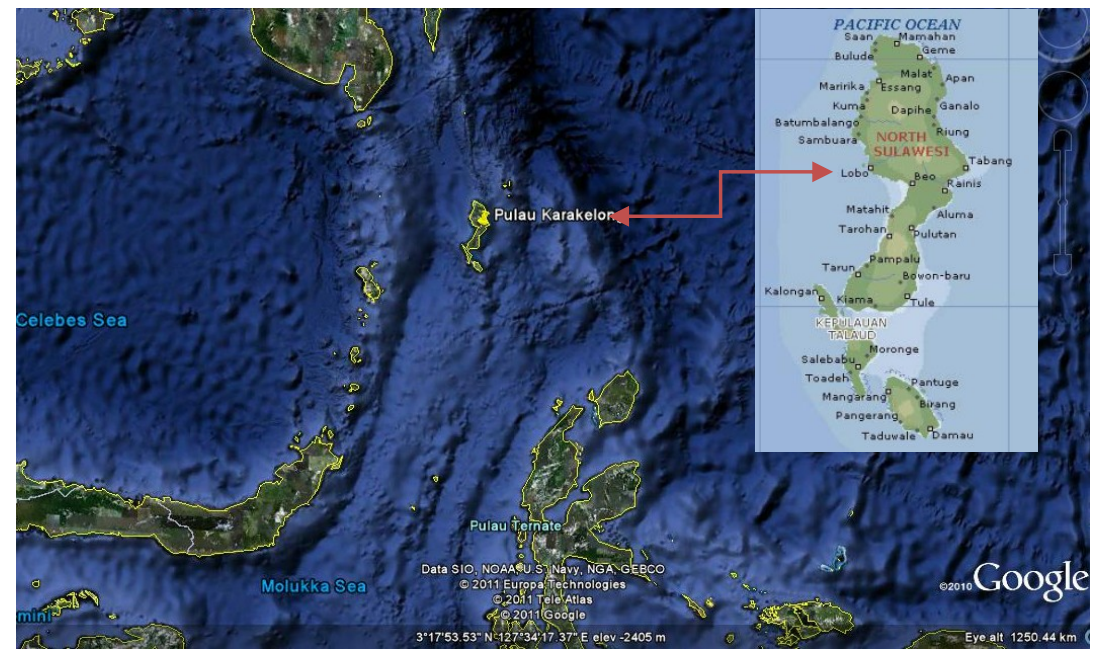

Peta 1. Pulau Karakelong di Gugusan Kepulauan Talaud, Sulawesi Utara

Secara astronomi wilayah Kepulauan Talaud membentang dari utara ke selatan antara $3^{\circ} 45^{\prime}-5^{\circ}$ Lintang Utara dan membujur dari Barat ke Timur antara 126 $30^{\prime}$ $126^{\circ} 45^{\prime}$ Bujur Timur yang terdiri dari gugusan pulau-pulau besar dan kecil. Secara geologis, pulau-pulau di wilayah Kepulauan Talaud umumnya tidak memiliki gunung api yang aktif, sebagian besar daerah-daerah pesisir merupakan daerah berbatu yang terbentuk akibat pengangkatan satuan koral. Pada daerah inilah terbentuk ceruk-ceruk maupun gua-gua (Siswanto, 2001)

Menurut Schmidt dan Ferguson dalam Data Stasiun Meteorologi di Naha (2002), Kabupaten Kepulauan Talaud termasuk tipe iklm A (iklim basah) yang selanjutnya menurut Koppen termasuk dalam tipe AFA Hal ini menunjukkan bahwa wilayah tersebut memiliki curah hujan berkisar antara $2500 \mathrm{~mm}$ - $3500 \mathrm{~mm} / \mathrm{tahun}$. Keadaan ini dipengaruhi oleh putaran atau pertemuan arus angin dan udara sehingga menyebabkan curah hujan beragam menurut bulan. Suhu udara di wilayah kepulauan ini dipengaruhi oleh tinggi rendahnya tempat dari permukaan laut dan jaraknya dari pinggir pantai, suhu udara berkisar antara $26^{\circ}-30^{\circ} \mathrm{C}$. Sebagai daerah tropis dan daerah kepulauan, 
Kepulauan Talaud mempunyai kelembaban nisbi tinggi yaitu berkisar $82 \%-89 \%$ dengan rata-rata 85,5\% (Sumber data Stasiun Meteorologi di Naha, 2002).

Berdasarkan sumber data dari Badan Pertanahan Nasional, keadaan topografi Kabupaten Kepulauan Talaud termasuk datar dan sebagian kecil bergelombang, tinggi tempat berkisar antara $0-850$ meter dari permukaan laut.

Sebagai wilayah yang strategis di kawasan Pasifik karena merupakan jembatan penghubung antara kawasan Asia dengan Kepulauan Pasifik serta memiliki sejarah route perjalanan migrasi fauna dan karena letaknya yang jauh di perbatasan Philipina, sehingga pulau ini kurang menjadi minat manusia beserta kebudayaannya yang menjadikan wilayah ini sangat istimewa dan penting, tetapi dari sudut kepariwisataan kurang mendapat perhatian dari pemerintah wisatawan mancanegara maupun local untuk mengunjunginya

Dengan melihat keadaan alam baik biotis maupun abiotis maka wilayah kawasan Pulau Karakelong sangat berpotensi untuk dijadikan objek tujuan wisata, khususnya wisata alam atau wisata ekologi. Pembangunan ekowisata di daerah ini merupakan salah satu pembangunan yang perlu dikembangkan karena dari sektor ini dapat meningkatkan penerimaan devisa daerah, memperluas lapangan kerja serta memperkenalkan kebudayaan bangsa dan tanah air

\section{METODE PENELITIAN}

Dengan tujuan untuk mengetahui potensi wisata di pulau ini, dapat dilakukan dengan melakukan penelitian lingkungan dan penelitian arkeologi. Penelitian lingkungan terutama lingkungan vegetasi dilakukan dengan metode observasi/survei lingkungan alam, sedangkan penelitian arkeologi dilakukan dengan menggunakan metode survei, ekskavasi, dan laboratoris

\section{POTENSI SUMBER DAYA ALAM PULAU KARAKELONG, TALAUD}

Kekayaan keanekaragaman hayati di pulau Karakelong ini dapat dilihat dari hasil survei lingkungan alam yang yang pernah dilakukan di wilayah ini. Dari penelitian yang dilakukan dengan menggunakan metode survei lapangan terhadap lingkungan baik abiotis/fisik maupun biotis, maka secara fisik, pulau ini cukup banyak memiliki gua-gua dengan berbagai ukuran. Jika dilihat dari keadaan fisik gua-gua ini, maka gua-gua ini berpotensi besar dapat dijadikan daerah tujuan wisata pulau ini. Gua-gua tersebut antara lain:

\section{Gua Wetta}

Gua Wetta berada di Desa Rainis, Kecamatan Rainis pada ketinggian \pm 80 meter diatas permukaan laut. Lingkungan vegetasi disekitar gua berupa tumbuhan semak belukar, Perkebunan cengkeh (Eugenia aromatica), pala (Myristica fragrans) dan vanili (Vanilla planifolia) dan berjenis-jenis pohon-pohonan hutan seperti dari kelompok famili Bombacaceae, Urticaceae, Arecaceae, Myrtaceae, Euphorbiaceae, Sterculiaceae, Pandanaceae, Moraceae, sedangkan tumbuhan semak belukar disusun oleh kelompok Araceae, Poaceae,Piperaceae, Zingiberaceae, dan Gesneriaceae.

Keadaan lingkungan di sekitar gua cukup lembab, sehingga berbagai jenis tumbuhan pakis dapat hidup pada lingkungan ini antara lain dan kelompok Polypodiaceae, Asplenium group, dan Nephrolepis group. 


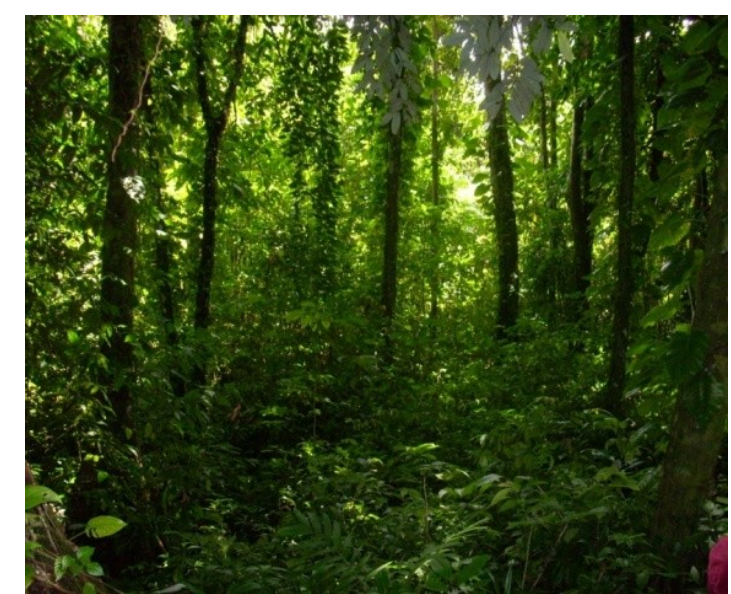

Foto 1. Lingkungan vegetasi Gua Wetta (Dok. Vita, 2007)

\section{Gua Totombatu}

Gua ini terletak di Desa Tarohan, Kecamatan Beo, berada di pinggir pantai pada tebing karang yang menjorok ke laut dengan ketinggian \pm 5 meter diatas permukaan laut. Lingkungan gua selain berupa batu-batu karang di pinggir pantai juga disusun oleh berjenis-jenis tumbuhan pantai yang berukuran cukup besar seperti, Teminalia catappa, Callophyllum inophylum, Hernandia peltata, Hibiscus tiliaceus, Guetarda speciosa, Baringtonia asiatica, Morinda citrifolia, Xylocarpus granatum, Pongamia pinnata, Cerbera manghas, Pandanus tectorius, Erythrina orientalis, Crinum asiaticum, dan berjenis-jenis tumbuhan Poaceae, tidak jauh dari gua ini terdapat komunitas mangrove dari jenis Rhizophora stylosa yang menyukai tumbuh pada pantai berpasir atau berbatu koral. Jenis ini lebih tahan pukulan ombak.

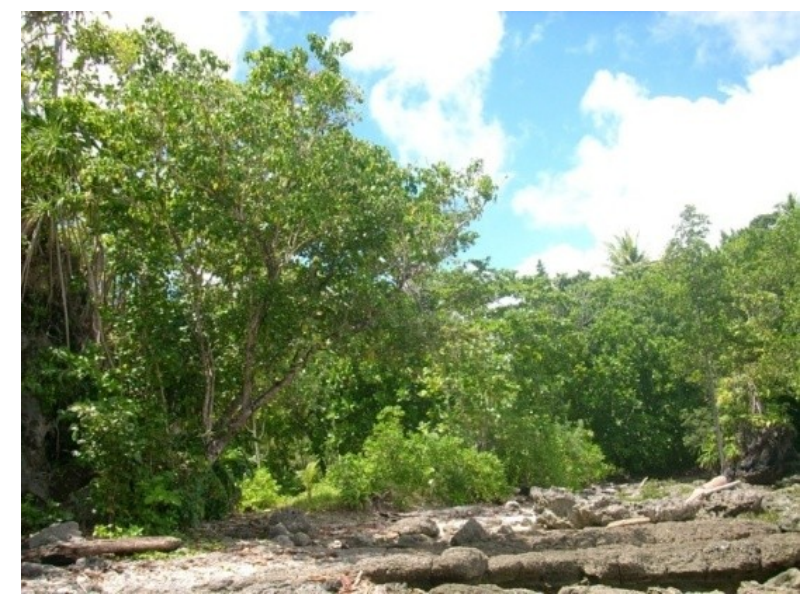

Foto 2. Lingkungan vegetasi Gua Totombatu, Desa Tarohan, Kecamatan Beo (Dok. Vita, 2007)

\section{Gua Wointumbu}

Gua ini terletak di Desa Beo, Kecamatan Beo pada lereng bukit karang pada ketinggian \pm 100 meter dari permukaan laut yang ditempuh dengan berjalan kaki sepanjang $3 \mathrm{~km}$ dari jalan raya. Untuk mencapai gua ini terlebih dulu harus melewati perkebunan kelapa (Cocos nucifera), cengkeh (Eugenia aromatica), pala (Myristica fragrans). Lingkungan gua ini terdiri dari vegetasi yang cukup lebat seperti pala hutan (Myristica sp.), meranti (Shorea sp.), kenari hutan (Canarium sp.), gehe (Pometia pinata), Albizia sp., Macaranga gigantea, Diospyros sp. Kleinhovia hospita, (kelompok tumbuhan Moraceae, Sterculiaceae Sapotaceae, Ebenaceae, dan Gnetaceae. 
Keadaan lingkungan disekitar gua cukup lembab yang disebabkan oleh rimbunnya tajuk-tajuk pohon disekitar gua. Itu juga kenapa jenis paku-pakuan cukup banyak ditemukan di sekitar gua ini.
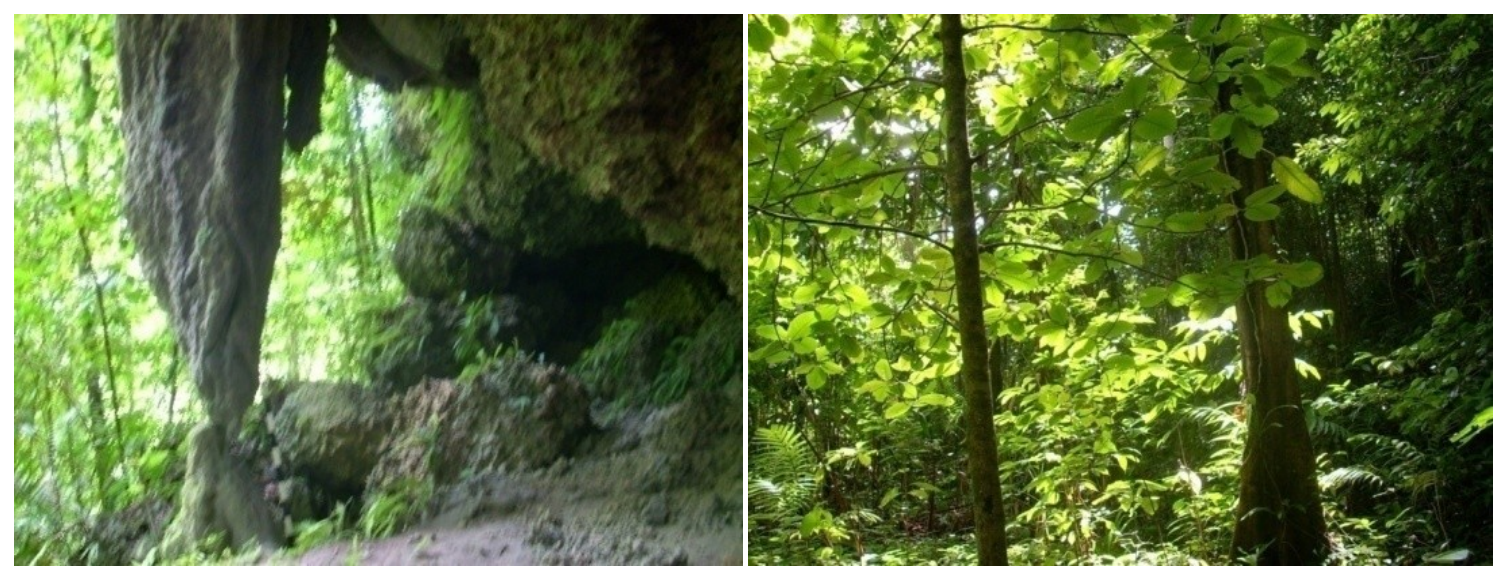

Foto 3. Lingkungan vegetasi Gua Wointumbu dengan berbagai jenis pohon dan semak belukar (Dok. Vita, 2007)

\section{Gua Balangingi}

Gua ini terletak di sebelah timur Desa Rainis, Kecamatan Rainis. Gua ini merupakan gua payung yang menghadap ke tenggara. Kondisi gua cukup terang, hal ini disebabkan kurangnya jenis tumbuhan/pohon besar di sekitarnya, sehingga sinar matahari dapat masuk ke dalam gua. Pada umumnya lingkungan vegetasi gua ini terdiri dari tumbuhan semak belukar seperti Araceae, Gesneriaceae, Zingiberaceae, Piperaceae, Poaceae, Pandanaceae, dan Pteridaceae. Beberapa anakan pohon juga terdapat di sekitar gua, seperti dari kelompok Arecaceae, Moraceae, Myristicaceae, Euphorbiaceae, Burseraceae, Malvaceae, Cluciaceae, dan lain-lain
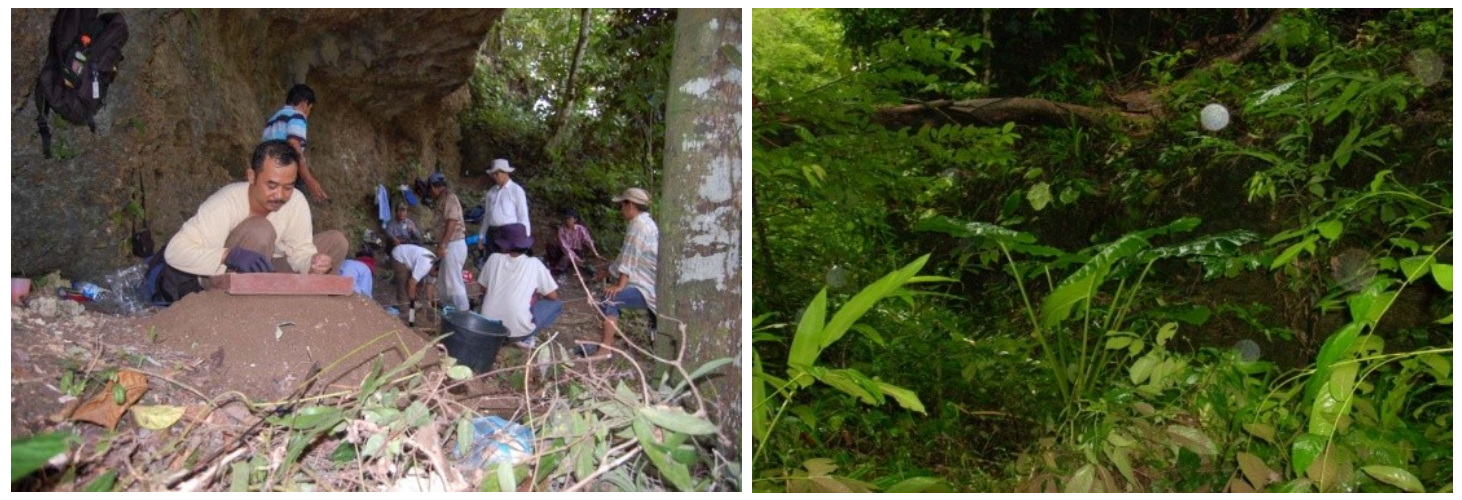

Foto 4. Lingkungan vegetasi Gua Balangingi yang terdiri dari tumbuhan semak belukar (Dok. Vita, 2007)

\section{Gua Matahit}

Gua Matahit terletak di Desa Matahit, Kecamatan Beo. Gua ini terletak pada areal semak belukar dan perkebunan pala (Myristica fragrans), Berjenis-jenis tumbuhan herbaceous dan frutescens terdapat di sekitar gua, seperti Zingiberaceae, Araceae, Orchidaceae, Pteridaceae, Poaceae, Begoniaceae, Mimosaceae, dan Musaceae. 


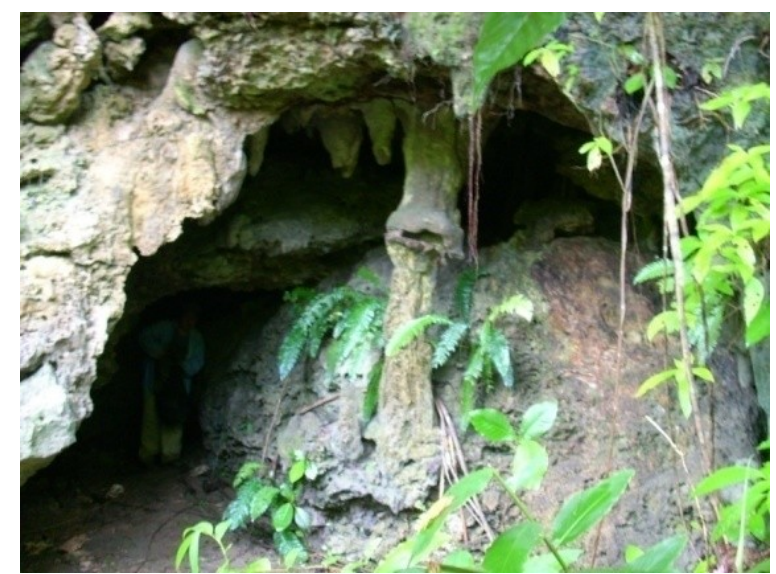

Foto 5. Keadaan lingkungan Gua Matahit, Desa Matahit, Kecamatan Beo

(Dok. Vita, 2007)

Survei yang dilakukan secara biotis terutama terhadap lingkungan tumbuhan (flora) di pulau Karakelang, khususnya di Kecamatan Beo (desa Beo, Tarohan dan Matahit) serta kecamatan Rainis (Desa Rainis) maka secara fisiognomi lingkungan tumbuhan dapat dibagi atas:

1. Lingkungan vegetasi pantai

2. Lingkungan vegetasi tanaman perkebunan

3. Lingkungan vegetasi semak belukar

4. Lingkungan vegetasi hutan

\section{Lingkungan Vegetasi Pantai.}

Daerah pantai merupakan daerah perbatasan antara ekosistim darat dan ekosistim laut. Berdasarkan susunan vegetasinya, vegetasi pantai dapat dibedakan menjadi 2 bagian yaitu formasi Pescaprae dan formasi Baringtonia.

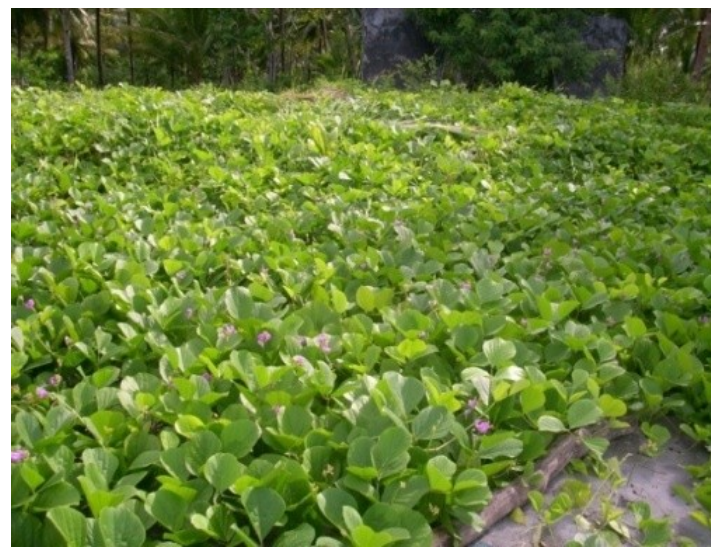

(a)

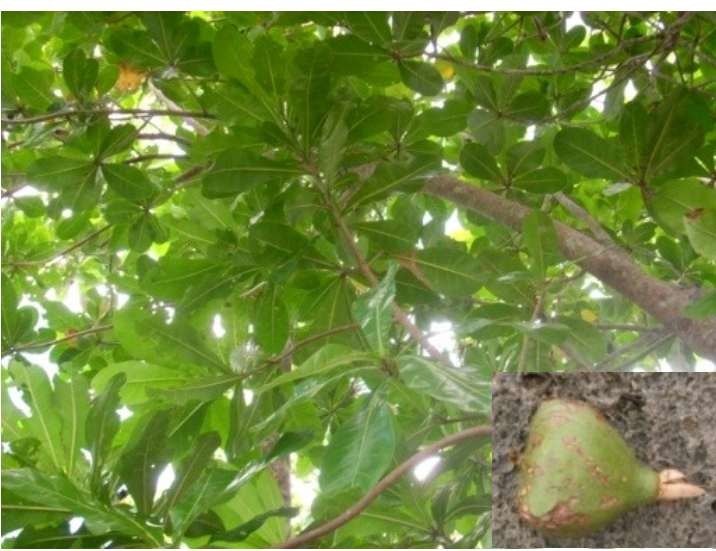

(b)

Foto 6. (a) Formasi Pes-caprae yang didominasi tumbuhan Ipomoea pes-caprae

(b) Pohon dan buah Baringtonia asiatica (Dok. Vita, 2007)

Dari hasil pengamatan, formasi pescaprae dijumpai di sepanjang pantai Rainis dan pantai Beo. Hal ini dapat dilihat dari jenis Ipomoea pescaprae yang sangat mendominasi sebagian pantai Rainis dan Beo. Selain jenis ini beberapa tumbuhan lain yang mencirikan formasi ini adalah jenis pandan berduri (Pandanus tectorius), bakung (Crinum asiaticum), rumput angin (Spinifex litoralis), sedangkan pada formasi Baringtonia dijumpai berbagai jenis tumbuhan pantai yang didominasi oleh jenis Baringtonia asiatic. Formasi Baringtonia ini ditumbuhi oleh vegetasi yang tahan terhadap siraman air asin, mampu hidup pada 
tanah yang miskin zat, hara serta tahan kekeringan seperti habitat yang berbatu-batu serta batu karang bercampur pasir.

\section{Lingkungan Vegetasi Tanaman Perkebunan}

Sebagian besar masyarakat Kecamatan Rainis maupun kecamatan Beo merupakan petani dengan membudidayakan tanaman cengkeh (Eugenia aromatica), pala (Myristica fragrans), kelapa (Cocos nucifera) dan panili (Vanilla planifolia) sebagai komoditi andalan pulau ini

Lingkungan vegetasi seperti ini umum dijumpai pada hampir seluruh daerah pengamatan. Ekosistem alami telah berubah menjadi kawasan perkebunan/pertanian yang disebabkan ulah manusia dengan masukan teknologi untuk mendapatkan suatu keluaran berupa bahan yang dapat memenuhi kebutuhan manusia langsung maupun tidak langsung serta mendapatkan nilai/arti ekonomis. Perubahan kawasan alami (ekosistem alami) menjadi kawasan pertanian/perkebunan biasa disebut juga dengan agroekosistim.

Selain cengkeh sebagai tanaman utama untuk perkebunan, tanaman kelapa termasuk jenis yang cukup diperhitungkan untuk menghasilkan kopra. Dari tanaman cengkeh yang dipanen adalah bunganya yang digunakan untuk rempah-rempah, campuran rokok kretek, obat dan sebagainya. Di samping bunga, tangkai bunga yang ikut dipetik dapat dijual yang diistilahkan dengan "sagang". Bunga maupun daunnya dapat juga dibuat minyak.

Menurut Ismal (1995) tanaman cengkeh menhendaki suhu udara antara $21^{\circ}-29^{\circ} \mathrm{C}$ dengan iklim basah. Curah hujan yang cocok antara $1500-3000 \mathrm{~mm} / \mathrm{tahun}$. Tanaman cengkeh tidak tahan dengan kekeringan. Tanaman akan gagal berbunga pada daerahdaerah yang mempunyai musim kering. Tanaman ini menghendaki tanah yang gembur dan drainase baik.

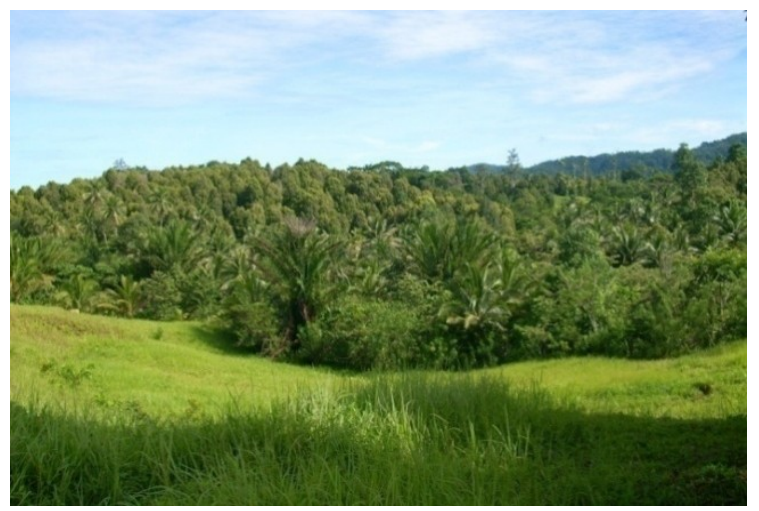

Foto 7. Tanaman cengkeh (Eugenia aromatica) dan kelapa (Cococs nucifera) sebagai tanaman perkebunan yang utama di Kecamatan Beo dan Rainis (Dok. Vita, 2007).

Tanah-tanah yang berupa lereng dan menghadap matahari terbit sangat baik untuk pertanaman cengkeh. Jenis tanah yang baik untuk penanaman cengkeh adalah tanah yang berasal dari jenis latosol, andosol dan podsolik.

Kelapa merupakan tanaman penghasil minyak nabati yang terpenting. Seluruh bagian tanaman kelapa sangat bermanfaat, untuk bahan industri seperti sabun dan margarine. Bahan ekspor utama dari tanaman ini berupa kopra yang diambil dari endosperm biji yang dikeringkan. Menurut Mortensen dan Bullard (1964) tanaman kelapa tumbuh baik pada latitude dari equator sampai $15^{\circ}$. Tinggi tempat yang diinginkan berkisar antara 0 - 300 meter dari muka laut. Pada latitude dan altitude yang lebih tinggi juga dapat hidup, tetapi dari segi kualitas buah kurang bagus. Suhu yang dibutuhkan untuk perkembangannya berkisar antara $25^{\circ}-29^{\circ} \mathrm{C}$, sedangkan curah hujan yang dikehendaki minimum 1500 mm/tahun dan merata sepanjang tahun dan menyukai tanah- 
tanah berpasir di pinggir pantai. Aerasi dan drainase tanah yang baik akan mendorong pertumbuhan akar yang sempurna.

Di samping tanaman perkebunan sebagai komoditi andalan, wilayah ini memiliki potensi pertanian tanaman pangan dan hortikultura yang memiliki nilai ekonomis yang dapat dikembangkan seperti padi sawah, padi ladang, jagung, kedele, kacang tanah, kacang hijau, umbi-umbian, sagu, palawija dan berbagai buah-buahan seperti mangga, jeruk, pisang, nanas dan tomat.

\section{Lingkungan Vegetasi Semak Belukar}

Lingkungan vegetasi semak belukar dijumpai pada lahan yang tidak dimanfaatkan oleh masyarakat setempat, seperti di tegalan-tegalan/ pinggir jalan. Vegetasi semak belukar ini terjadi akibat terganggunya vegetasi asli oleh manusia, misalnya untuk pembuatan jalan, ataupun bangunan-bangunan untuk pemukiman, di samping disebabkan oleh bencana alam, misalnya tumbangnya pohon akibat longsor.

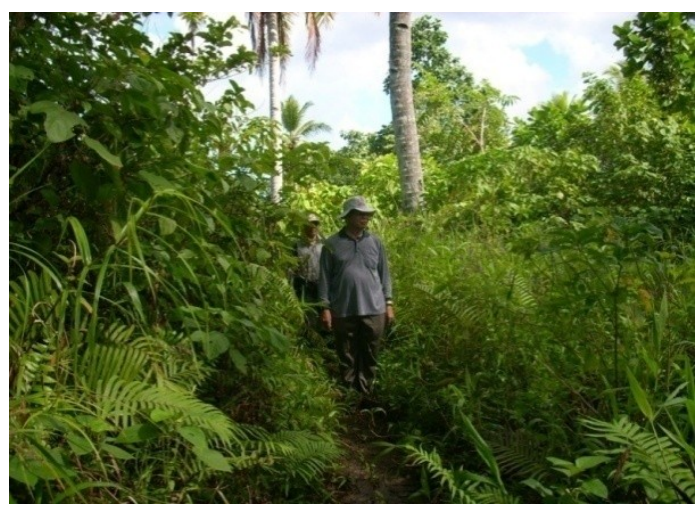

Foto 8. Bentuk lingkungan vegetasi semak belukar, tampak jenis Macaranga yang merupakan jenis tumbuhan pionir menuju vegetasi semula (hutan)

(Dok. Vita, 2007)

Lingkungan seperti ini dijumpai di sepanjang jalan dari Desa Beo ke Desa Rainis maupun dari Desa Beo menuju Melonguane. Jenis tumbuhan yang mendominasi vegetasi seperti ini berupa jenis Mallotus, Macaranga, Melastoma, Muntingia sp., dan Poaceae. Adanya jenis Macaranga dalam kelompok vegetasi ini menunjukkan bahwa terjadi perkembangan dari lingkungan vegetasi ini menuju ke bentuk vegetasi semula (hutan).

\section{Lingkungan Vegetasi Hutan}

Hutan adalah suatu kesatuan ekosistem berupa hamparan lahan yang berisi sumberdaya alam hayati yang didominasi oleh pepohonan dalam persekutuan alam lingkungannya yang tidak dapat dipisahkan satu sama lainnya, sedangkan yang dimaksud dengan kawasan hutan adalah suatu wilayah tertentu yang ditunjuk atau ditetapkan oleh pemerintah untuk dipertahankan keberadaannya sebagai hutan tetap. Hutan tidak semata-mata memiliki fungsi ekologi, tetapi berkaitan dengan masyarakat di sekitarnya yang memiliki fungsi sosial (Hendro, 1982)

Menurut Indriyanto (2006) jika dilihat pada ketinggian tempat dari permukaan laut, vegetasi hutan tropis dapat dibedakan atas 3 zona, yaitu:

- Zona 1 dinamakan hutan hujan bawah karena terletak pada daerah dengan ketinggian antara $0-1000 \mathrm{~m}$ dari permukaan laut.

- Zona 2 dinamakan hutan hujan tengah (1000 - 3300 m dari permukaan laut)

- Zona 3 dinamakan hutan hujan atas (3300 - $4100 \mathrm{~m}$ dari permukaan laut). 
Berdasarkan sumber data Badan Pertanahan Nasonal di Kabupaten Satal (2000), keadaan topografi Kecamatan Beo sebagian besar termasuk datar sampai bergelombang dengan ketinggian berkisar antara 3 - 700 meter dari permukaan laut, sedangkan ketinggian Kecamatan Rainis berkisar antara 5 - 700 meter dari permukaan laut. Dari data ketinggian tersebut maka lingkungan vegetasi hutan di wilayah ini dapat dimasukkan kedalam zona 1 yaitu hutan hujan bawah.

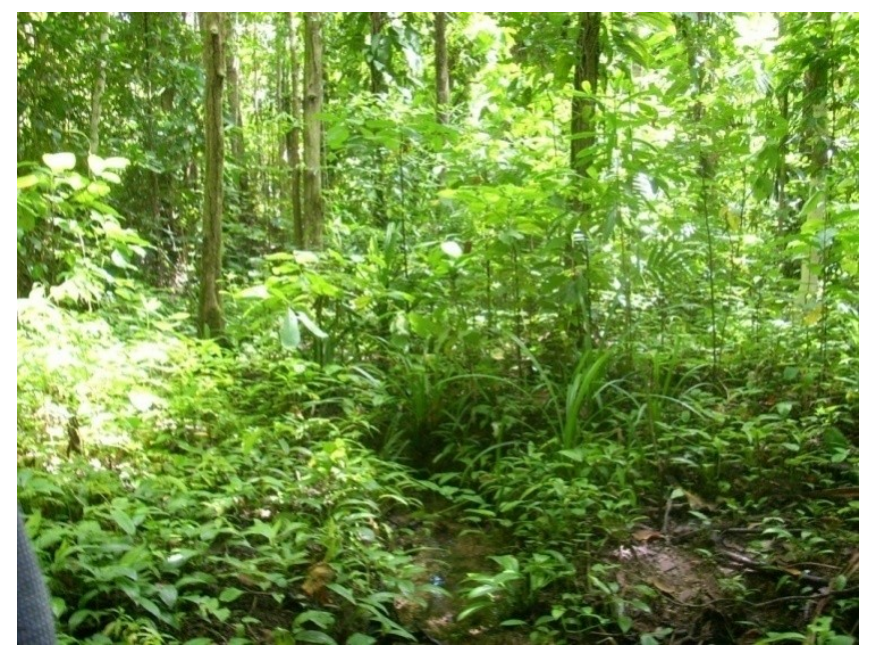

Foto 9. Beberapa jenis seedling (kecambah) dari pohon induk yang tumbuh dilantai hutan

(Dok. Vita, 2007).

Pada vegetasi hutan hujan bawah ini banyak ditemukan jenis tumbuhan dari kelompok Diospyros, Arecaceae, Moraceae, Myristicaceae, Euphorbiaceae, Burseraceae, Malvaceae, Myrtaceae, Cluciaceae, Sapotaceae serta tumbuhan merambat berupa liana seperti jenis Piperaceae, Convolvulaceae serta tumbuhan herbaceous lainnya dari jenis Zingiberaceae, Araceae, Gesneriaceae, dan lain-lain yang berasosiasi dengan tumbuhan paku-pakuan (Polypodiaceae), lumut, dan jamur pengurai.

Mengamati bentuk fisiognomi/kenampakan luar dari lingkungan vegetasi hutan yang memiliki pohon dengan batang yang lurus dan tinggi, batang berbanir, mesofil yang tegas, dengan tingkat keanekaragaman jenis yang tinggi dan adanya tumbuhan saprophyt serta ketinggian tempat lebih kurang 700 meter dpl maka lingkungan vegetasi hutan di wilayah Kecamatan Beo dan Kecamatan Rainis dapat dikelompokkan kedalam tipe Vegetasi Hutan Hujan Tropik Dataran Rendah. Menurut Indriyanto (2006) tipe vegetasi hutan hujan dataran rendah dapat dikelompokkan pada zona 1 yaitu Hutan Hujan Bawah.

\section{DATA ARKEOLOGI}

Menurut Wahyono dkk. (1992) proses penghunian pesisir pantai di Pulau Karakelong ternyata belum lama terjadi. Data-data sejarah lisan mengatakan bahwa daerah pantai mulai dihuni oleh manusia baru pada masa-masa masuknya pengaruh Belanda, yaitu sekitar abad ke-19, sedangkan berdasarkan data-data arkeologis, Bellwood (1985) menyebutkan bahwa proses penghunian pulau-pulau di Talaud pada umumnya telah dimulai sekitar 4000 SM. Data itu didukung pula dengan penelitian linguistik bandingan yang memperkirakan bahwa terdapat penyebaran ras Austronesia dari Cina Selatan ke arah selatan dengan melalui Taiwan, Filipina, Indonesia sampai ke Oseania. Jalur penyeberangan ini antara lain melewati kepulauan Sangihe dan Talaud. Para pemukim awal di Pulau Talaud umumnya bertempat tinggal di gua-gua, seperti di situs Leang Buidane di Pulau Salibabu dan Leang Tuwo Mane'e di Pulau Karakelong. Ekskavasi telah dilakukan di Situs Leang Buidane yang diperkirakan gua ini berasal dari masa logam awal, yaitu berkisar antara 200 SM - $1000 \mathrm{M}$. Temuan yang menarik dari situs ini adalah beberapa tempayan kubur dan juga fragmen-fragmen benda terbuat dari 
logam seperti kapak perunggu dan perhiasan, sedangkan Situs Leang Tuwo Mane'e di Pulau Karakelong merupakan situs pemukiman dengan pertanggalan relatif $4000-2500$ SM. Di sini ditemukan alat-alat batu berupa serpih bilah dan fragmen-fragmen gerabah dengan pertanggalan 2500 SM. Di samping itu ditemukan juga 94 jenis sisa-sisa binatang yang hidupnya di karang dan di lumpur.

Data arkeologi yang terdapat di Pulau Karakelong ini berupa gua-gua hunian yang salah satunya yaitu Situs Gua Balangingi. Di Situs ini telah didapatkan lebih dari 2604 pecahan gerabah, tiga manik-manik kaca berwarna merah dan dua manik-manik kaca berwarna hijau, dua fragmen perunggu / tembaga dan segmen gelang dari tembaga /perunggu. Sampel arang yang ditemukan pada kedalaman 20-30 cm telah ditentukan umur pertanggalan $\mathrm{C}^{14}$ nya sekitar $950 \pm 130 \mathrm{BP}$ pada lapisan budaya bagian tengah (Tanudirjo, 2001).

Triwurjani (http://www.hariankomentar.com/arsip/arsip 2007/ags 04/hl003.html) pada pemaparan hasil penelitian di Kantor Pemkab Kepulauan Talaud, 31 Juli 2007 lalu menyatakan bahwa penelitian arkelogi berhasil menemukan sejumlah benda purbakala yang diyakini sisa peninggalan manusia purba Talaud berumur 3.000-4.000 tahun SM. Benda-benda bernilai sejarah ini tersimpan di Goa Balangingi. Dalam penelitian yang dilakukan melalui metode survei penggalian dan analisis laboratoris (analisis palinologi), ditemukan sejumlah benda-benda peninggalan manusia Talaud pada zaman dulu, diantaranya tempayan, bekal kuburan, gigi manusia, manik-manik, sisa-sisa kerang dan masih banyak lagi barang yang ditemukan di dalam Goa Balangingi. Sementara Prof. Ris. Dr Haris Sukendar (http://www.hariankomentar.com/arsip 2007/ags04/hl003.html) yang juga merupakan salah satu tim dalam penelitian tersebut memaparkan bahwa banyak aset untuk pengembangan pariwisata Talaud yang ada. "Itu seperti peninggalan sisa-sisa pemukiman goa dan sisa-sisa penguburan," tuturnya. Selain itu, gua-gua Talaud memiliki persamaan dengan berbagai lokasi di Indonesia dan kawasan luar Indonesia dan mengandung nilai-nilai yang bersifat lokal, nasional, regional bahkan internasional. "Peninggalan arkeologi di Talaud yang berupa goa-goa dengan berbagai peninggalan arkeologinya sangat penting dalam merekonstruksi sejarah lokal, sejarah Indonesia bahkan sejarah Asia Tenggara. urainya. Dan berdasarkan tipologi peninggalan arkeologi, di mana Talaud memiliki persamaan dengan budaya di Taiwan, Filipina, Malaysia dan di berbagai lokasi di Indonesia, sehingga kesamaan hasil budaya, membuktikan bahwa budaya di berbagai negara Asia Tenggara berasal dari satu budaya dan satu bangsa.

"Sumber daya arkeologi yang ditemukan di goa-goa Talaud telah memberikan bukti kuat bahwa Talaud mempunyai peranan sebagai jembatan migrasi budaya dan bangsa yang penting dalam penyusunan kesejarahan dunia. Talaud mempunyai sumber daya arkeologi yang dapat membuktikan terjadinya arus migrasi bangsa dan budaya dari daratan Asia ke Taiwan, Filipina, Malaysia, Kalimantan Utara, Sulawesi Utara dan Pasifik, sehingga Talaud penting dalam penelitian arkeologi. Sementara itu hasil penelitian yang telah dilakukan oleh tim dari Puslitbang Arkeologi Nasional (2007) menunjukkan pula bahwa sebagian gerabah hias yang ditemukan pada ekskavasi di Gua Balangingi memiliki hiasan tipe Rarangunusa, disini terdapat juga adanya gerabah yang memiliki slip merah, di samping itu terdapat juga berbagai temuan arkeologi seperti, tempayan, bulibuli yang diperkirakan gerabah-gerabah tersebut berfungsi sebagai bagian dari peralatan upacara penguburan, berbagai pecahan tempayan yang diduga digunakan sebagai wadah kubur. Hasil analisis pendahuluan terhadap gerabah di situs Gua Balangigi diketahui adanya tipe gerabah berdinding tebal yang merupakan sisa kubur tempayan. Tipe-tipe gerabah (tempayan) Talaud ini menyerupai kubur-kubur tempayan dari bebagai tempat di Indonesia seperti di Plawangan. 

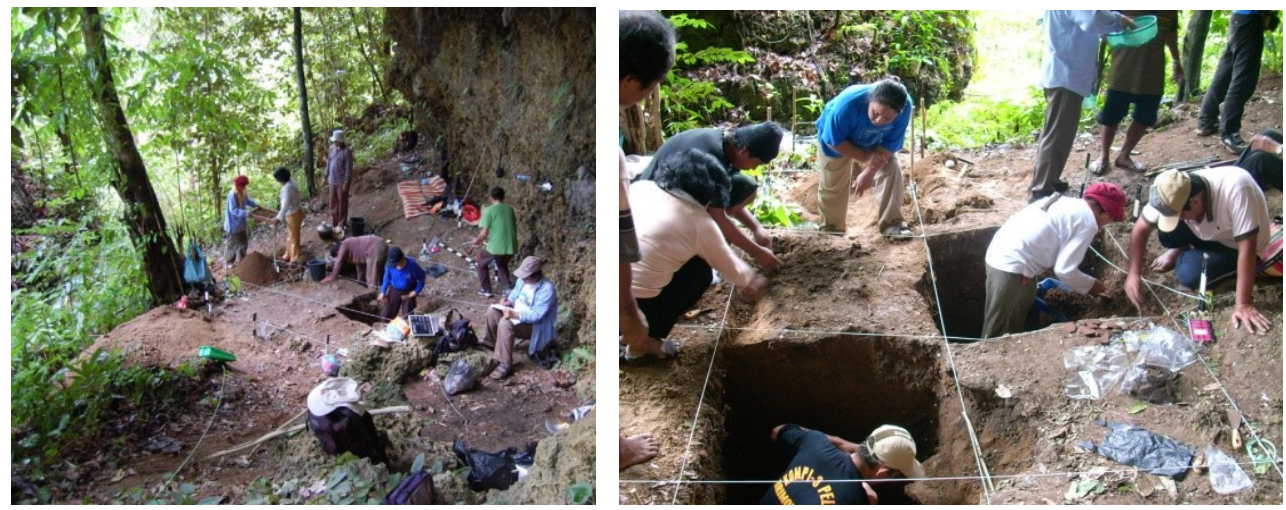

Foto 10. Kegiatan penelitian arkeologi yang di lakukan oleh Tim Puslitbang Arkeologi di Gua Balangingi, Pulau Karakelang, Talaud

(Dok. Puslit Arkenas, 2007)

Jika dilihat dari aspek teknologi pembuatan gerabah, maka diperkirakan ada persamaan tradisi pembuatan gerabah situs Balangingi dengan situs lainya di Indonesia yaitu sudah mempergunakan teknik dengan atau tanpa roda pemutar. Di samping temuan pecahan gerabah, tim peneliti Puslitbang Arkenas (2007) juga menemukan manik-manik dan periuk kecil dengan pola-pola hias bermotifkan garis lurus, tumpal, garis bergelombang, dan setengah lingkaran. Temuan manik-manik, artefak gerabah berukuran kecil maupun non artefak di Balangingi berasosiasi dengan kubur tempayan yag ditandai dengan temuan gigi manusia yang diduga merupakan sisa-sisa penguburan serta terdapatnya fosil pollen (benang sari) dari jenis tumbuhan dari kelompok Poaceae (padi-padian), Pteridaceae (paku-pakuan), Papilionaceae (polong-polongan), Malvaceae (kapas-kapasan) dan lain sebagainya yang diduga merupakan jenis tanaman yang diikutsertakan pada waktu penguburan.
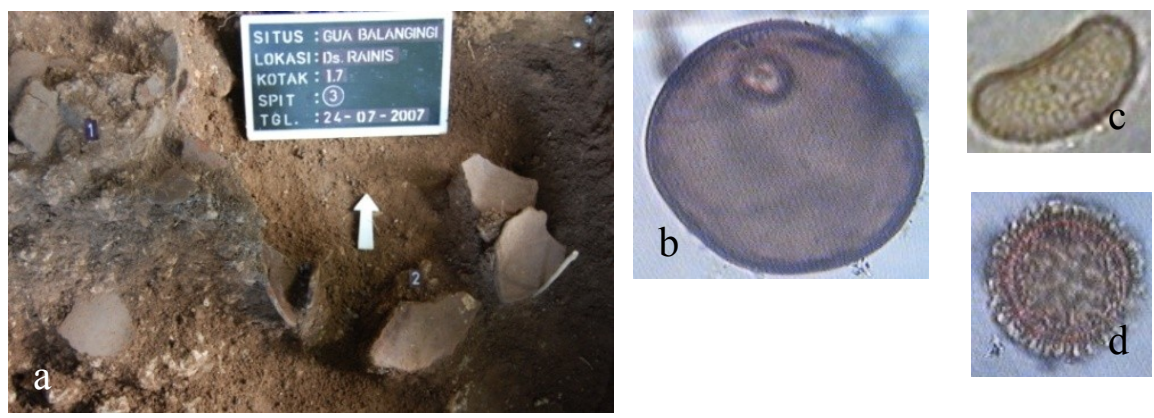

Foto 11. a. Fragmen gerabah pada kotak I.7; Fosil benang sari tumbuhan b. Poaceae; c. Pteridaceae; d. Malvaceae (Dok. Vita, 2007).

\section{PEMBAHASAN}

Indonesia memiliki potensi sumber daya alam dan peninggalan sejarah, serta seni dan budaya yang sangat besar sebagai daya tarik pariwisata dunia. Sebagai negara yang terletak di wilayah tropis, Indonesia mempunyai keanekaragaman jenis baik flora maupun fauna yang banyak tersebar di seluruh pulau-pulau di Indonesia.

Kekayaan berupa keaneka-ragaman hayati merupakan daya tarik utama bagi pangsa pasar kepariwisataan khususnya di bidang ekowisata, sehingga kualitas, keberlanjutan dan pelestarian sumber daya alam, peninggalan sejarah dan budaya menjadi sangat penting untuk tujuan wisata. Pengembangan ke-ekowisata-an juga memberikan peluang yang sangat besar, untuk mempromosikan pelestarian keanekaragaman hayati Indonesia di tingkat internasional, nasional, regional dan lokal. 
Pulau Karakelong yang merupakan salah satu dari sekian banyak jumlah pulau di Indonesia ini cukup banyak menyimpan kekayaan alam baik flora, fauna maupun dari faktor landscapenya. Di samping itu pulau ini cukup banyak menyimpan sejarah kebudayaan masa lampau. Hal ini telah dibuktikan oleh Bellwood (1985) menyebutkan bahwa proses penghunian pulau-pulau di Talaud pada umumnya telah dimulai sekitar 4000 SM. Data itu didukung pula dengan penelitian linguistik bandingan yang memperkirakan bahwa terdapat penyebaran ras Austronesia dari Cina Selatan ke arah selatan dengan melalui Taiwan, Filipina, Indonesia sampai ke Oseania

Salah satu pulau di Kepulauan Talaud ini yaitu di Pulau Karakelong banyak ditemukan gua-gua hunian, yang salah satunya adalah Situs Gua Balangingi. Di Situs ini telah didapatkan lebih dari 2604 pecahan gerabah, tiga manik-manik kaca berwarna merah dan dua manik-manik kaca berwarna hijau hijau, dua fragmen perunggu / tembaga dan segmen gelang dari tembaga /perunggu. Sampel arang yang ditemukan pada kedalaman $20-30 \mathrm{~cm}$ telah dapat ditentukan umur pertanggalan C 14 nya sekitar $950 \pm 130$ BP pada lapisan budaya bagian tengah. (Tanudirjo, 2001).

Dalam penelitian yang dilakukan oleh Tim dari Puslitbang Arkenas melalui metode survei, ekskavasi dan analisis laboratoris ini, telah ditemukan sejumlah benda-benda peninggalan manusia Talaud pada zaman dulu. Seperti tempayan, bekal kuburan, gigi manusia, manik-manik, sisa-sisa kerang dan fosil benang sari tumbuhan (pollen) serta masih banyak lagi artefak-artefak yang ditemukan di dalam Goa Balangingi ini.
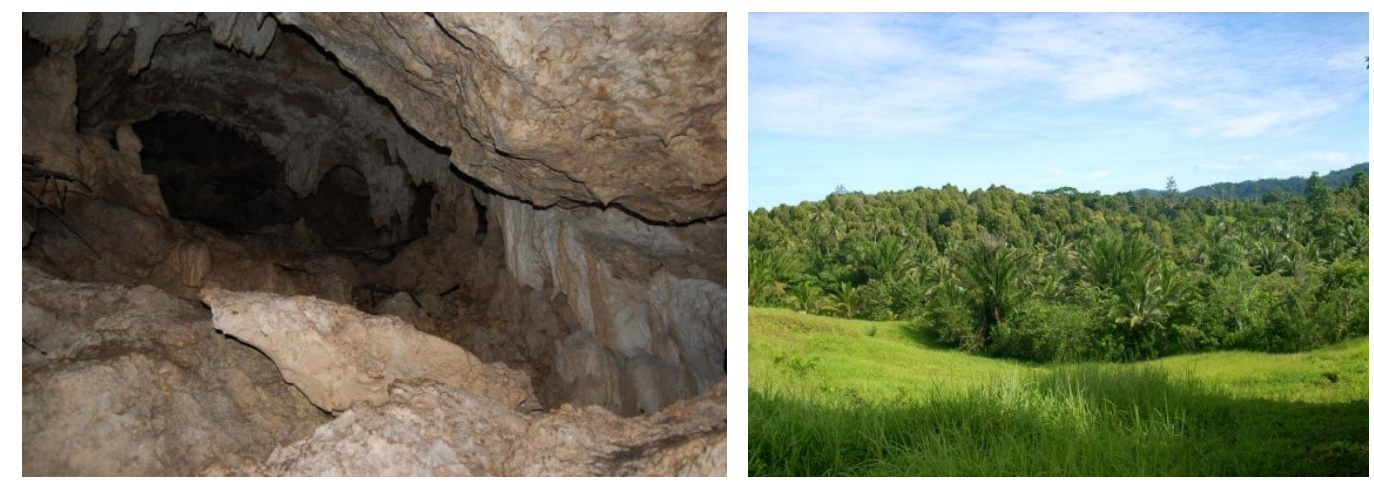

Foto 12. Salah satu sumber daya alam berupa kawasan perkebunan dan gua-gua

(Dok. Vita, 2007).

Pembangunan pariwisata memiliki masalah ekologi yang khusus. Sumber daya lingkungan yang dapat dieksploitasi untuk pariwisata didaerah ini cukup menjanjikan yang mempunyai daya tarik dan keindahan yang menonjol untuk wisatawan. Mengingat bahwa sumber daya ini dapat rusak karena gangguan pengunjung, maka perlu adanya penjagaan yang baik agar kualitas lingkungan pariwisata tetap terpelihara dan menarik. Pembangunan sarana dan prasarana harus tepat jangan sampai pembangunan pariwisata menyebabkan kerusakkan pada ekosistem.

Begitu banyak gua-gua alam yang terdapat di pulau ini dengan berbagai jenis fauna dan flora yang khas (endemik) yang menjadikan pulau ini mempunyai kekhasan tersendiri, seperti jenis burung nuri (Eos talaudensis) serta berbagai jenis flora dari jenis tumbuhan namnam (Fabaceae), anggrek macan (Orchidaceae), Zingiberaceae, Gesneriaceae, Euphorbiaceae dan beraneka jenis jamur (fungi) yang mencirikan daerah ini sebagai Lingkungan Hutan Hujan Dataran Rendah.

Dari hasil penelitian tersebut terlihat bahwa Kepulauan Talaud, khususnya Pulau Karakelong ini sangat penting dalam hal keanekaragaman hayati dunia, karena semakin tinggi tingkat kekhasan/keendemikan kehidupan liar ekosistim suatu daerah, semakin besar pula perhatian harus dicurahkan pada upaya konservasi dan keanekaragaman hayati di daerah ini. 

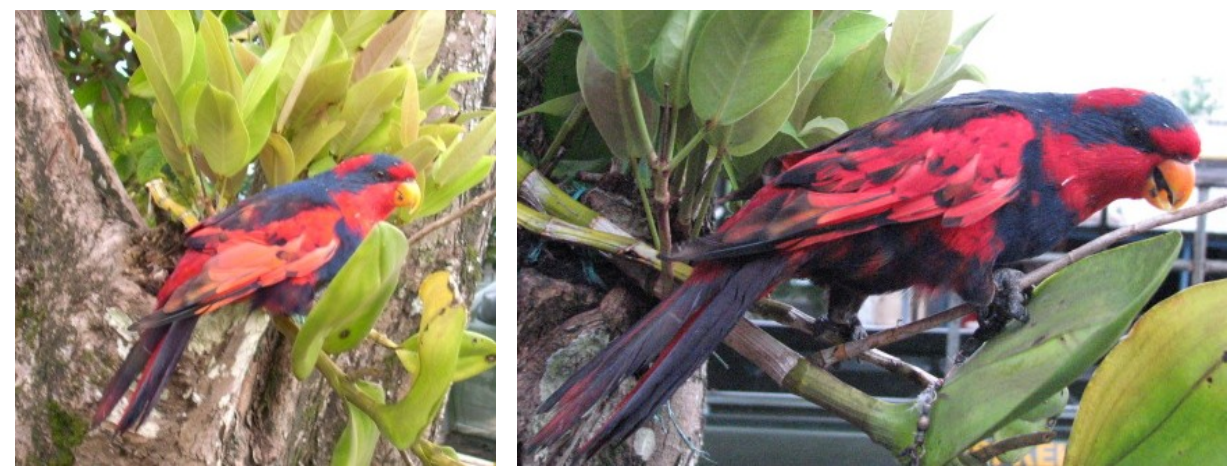

Foto 13. Burung Nuri (Eos Talaudensis)

(Dok. Vita, 2007)

Hutan yang masih ada saat ini tidak hanya penting untuk pelestarian keanekeragaman hayati yang khas dan unik itu, tetapi juga bagi kehidupan makhluk lainnya. Penting sebagai daerah tangkapan air, bagi irigasi, air minum masyarakat pesisir, pencegahan bahaya erosi dan lain sebagainya. Hutan-hutan di pulau ini merupakan lingkungan yang rapuh yang mudah rusak dan terganggu kelestariannya.

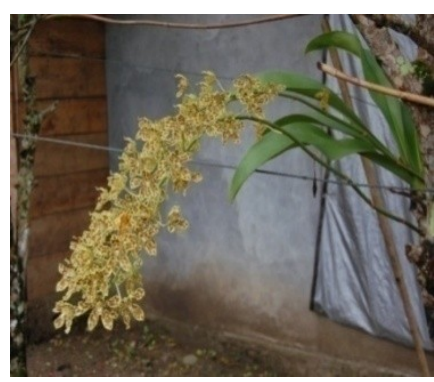

a

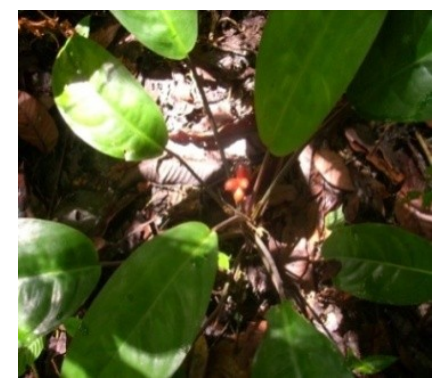

d

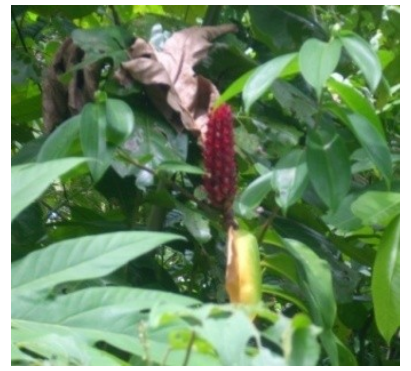

b

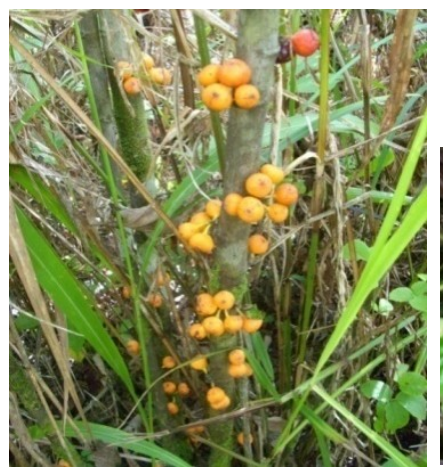

e

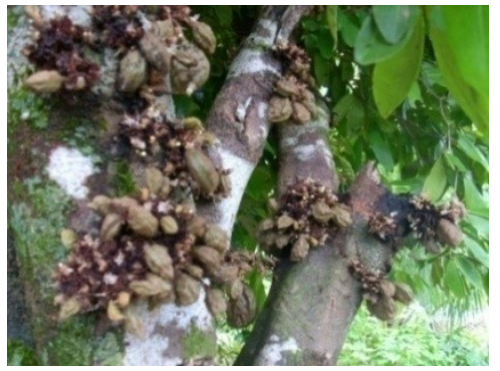

C

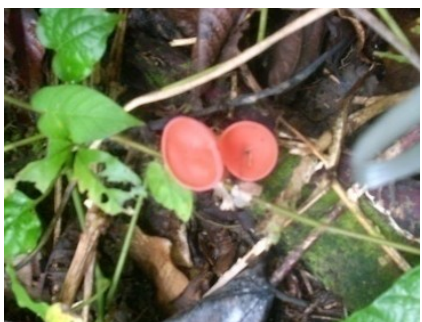

f

Foto 14. a. Orchidaceae; b. Zingiberaceae; c. Fabaceae; d.Gesneriaceae; e. Euphorbiaceae dan f. Fungi

(Dok. Vita, 2007)

Perencanaan lingkungan untuk pariwisata harus memperhitungkan berbagai daerah lingkungan fisik (seperti keadaan vegetasinya, sungai-sungai, air terjun, gua-gua atau tempat-tempat bersejarah lainnya) dan lingkungan sosio budaya di pulau ini. Oleh karena itu, perlu adanya perhatian terhadap sifat khas ekologi dari pulau ini. Pulau Karakelong yang dikelilingi oleh lautan mempunyai daerah pantai dengan pemandangan yang indah, iklim yang baik dan akan menarik perhatian sejumlah wisatawan. Tempat seperti ini menjadi tempat yang baik untuk olahraga air, berjemur atau kegiatan rekreasi lainnya 

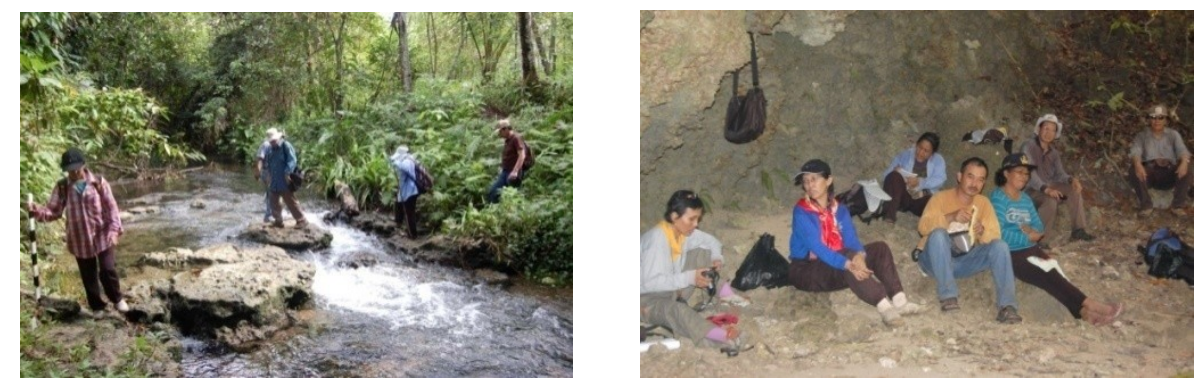

Foto 15. Berbagai kegiatan ekowisata yang dilakukan dengan melibatkan peneliti, masyarakat dan pejabat pemerintah di pedalaman Pulau Karakelong (Gua Balangingi)

(Dok. Puslit Arkenas, 2007)

Kebijakan pembangunan pariwisata yang dikaitkan dengan upaya pengelolaan lingkungan hidup, merupakan salah satu kebutuhan penting bagi pelayanan para wisatawan. Pembangunan pariwisata dan pengelolaan lingkungan hidup laksana dua sisi mata uang. Saling melengkapi dan dapat menjadi daya tarik dan pesona bagi wisatawan. Salah satu kegiatan wisata yang banyak dibicarakan akhir akhir ini, bahkan telah menjadi isu global yaitu dengan berkembangnya ekowisata (ecotourism) sebagai kegiatan wisata alam yang berdampak ringan terhadap lingkungan.
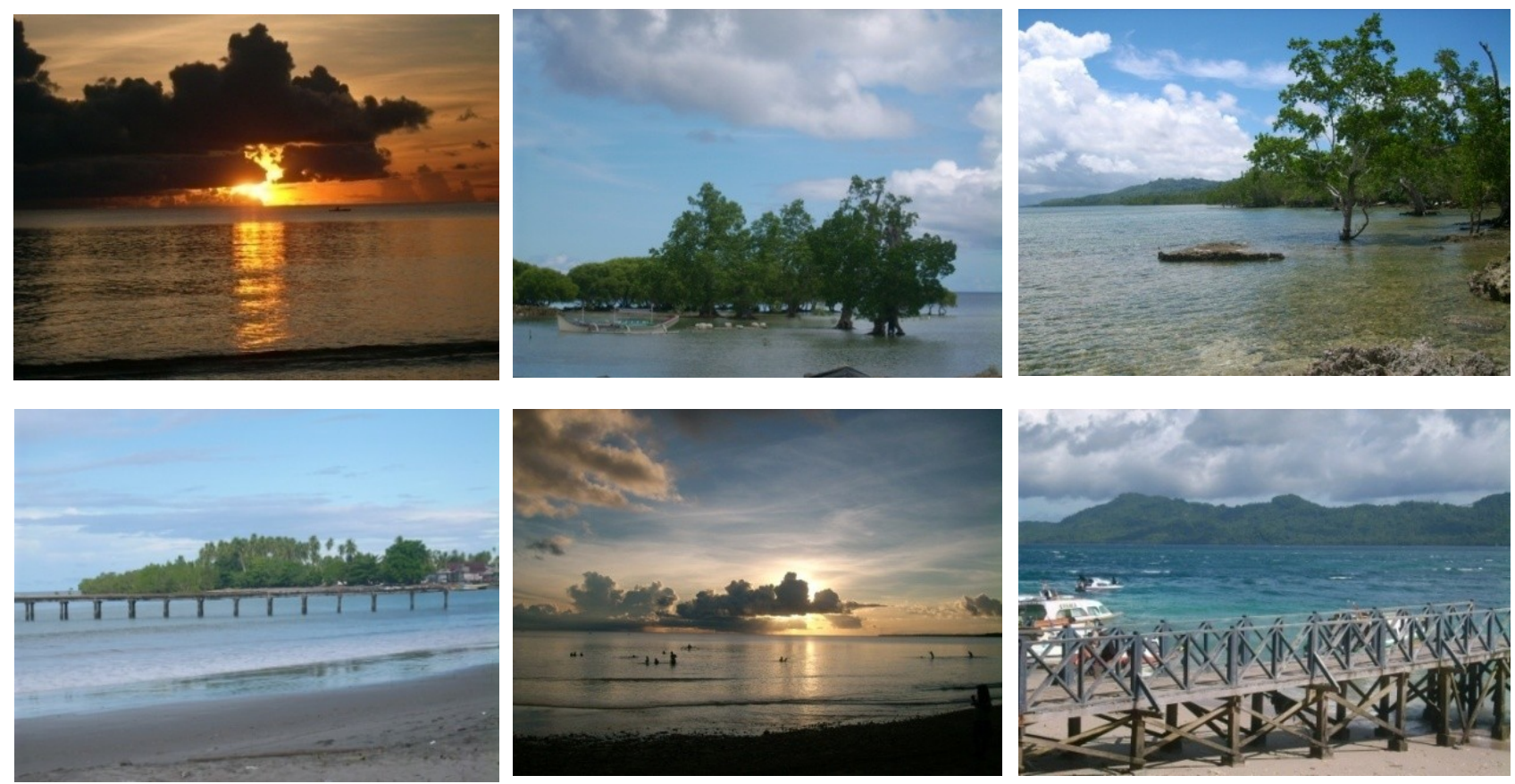

Foto 16. Pantai-pantai indah di wilayah Pulau Karakelong yang belum tersentuh oleh institusi pariwisata (Dok. Vita, 2007).

Menurut Choy (1997), ada 5 (lima) aspek utama untuk berkembangnya ekowisata adalah: (1) adanya keaslian lingkungan alam dan budaya (2) keberadaan dan daya dukung masyarakat (3) pendidikan dan pengalaman (4) berkelanjutan dan (5) kemampuan manajemen dalam pengelolaan ekowisata, sedangkan Hadi (2005) menyatakan bahwa prinsip-prinsip ekowisata (ecotourism) adalah meminimalisir dampak, menumbuhkan kesadaran lingkungan dan budaya, memberikan pengalaman positif pada turis (visitors) maupun penerima (hosts), memberikan manfaat dan pemberdayaan masyarakat lokal. Ekowisata dalam era pembangunan berwawasan lingkungan merupakan suatu misi pengembangan wisata alternatif yang tidak menimbulkan banyak dampak negatif, baik terhadap lingkungan maupun terhadap kondisi sosial budaya. 


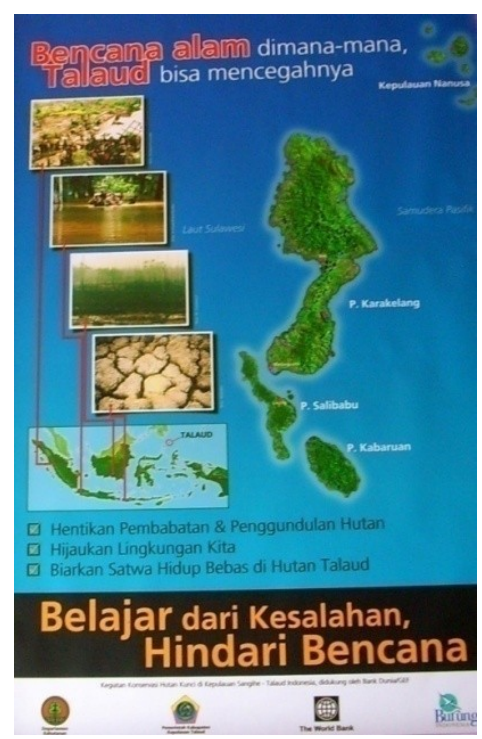

Foto 17. Himbauan-himbauan berupa slogan yang dipasang di tempat-tempat umum

(Dok. Vita, 2007).

Di tempat-tempat umum seperti di lapangan udara Melonguena dipasang sloganslogan untuk menghimbau pada masyarakat agar menjaga kelestarian alam, menghentikan pembalakan liar dan penggundulan hutan dan tak kalah pentingnya adalah hijaukan lingkungan kita, biarkan satwa hidup bebas di hutan Talaud, Dengan adanya himbauan tersebut, diharapkan wilayah ini akan menjadi daerah tujuan wisata di masa mendatang.

\section{PENUTUP}

\section{Kesimpulan}

Dari hasil dan pembahasan yang telah dilakukan, maka dapat disimpulkan bahwa kawasan Pulau Karakelong mempunyai potensi besar untuk dikembangkan sebagai salah satu objek tujuan ekowisata. Pada dasarnya ekowisata dapat dikembangkan dalam berbagai kawasan hutan seperti hutan produksi, hutan lindung dan konservasi. Hutan produksi merupakan kawasan yang mendominasi daerah tangkapan air. Ekowisata pada prinsipnya bukan menjual destinasi tetapi menjual ilmu pengetahuan dan filsafat lokal atau filsafat ekosistem dan sosiosistem.

Ekowisata sebagai sarana mewujudkan ekonomi berkelanjutan. Ekowisata memberikan peluang untuk mendapatkan keuntungan bagi penyelenggara, pemerintah dan masyarakat setempat, melalui kegiatan-kegiatan yang non-ekstraktif dan nonkonsumtif sehingga meningkatkan perekonomian daerah setempat. Penyelenggaraan yang memperhatikan kaidah-kaidah ekowisata, mewujudkan ekonomi berkelanjutan

\section{Saran}

Kepada pihak yang menentukan kebijakan disarankan agar melibatkan masyarakat dalam kegiatan kepariwisataan di wilayah ini. Masyarakat sekitar hutan perlu diberi pengarahan dan pengetahuan dalam pemeliharaan lingkungan baik dalam pemeliharaan hutan dan lingkungan pemukiman. Dengan demikian masyarakat akan berpartisipasi dalam kegiatan wisata, sehingga secara tidak langsung kerusakan hutan lebih lanjut dapat terhindari. Ekowisata di Pulau Karakelang ini diharapkan bermanfaat untuk masyarakat, pemerintah dan bagi akademisi dalam pengembangan ekowisata di pulau ini 


\section{KEPUSTAKAAN}

Bellwood, Peter. 1985. Prehistory of the Indo - Malaysian Archipelago, North Ryde: Academic Press.

Choy,D.L. 1997. Perencanaan Ekowisata. Belajar dari Pengalaman di South East Queesland. Proceedings on The Planning and Workshop of Planning Sustainable Tourism. Penerbit ITB Bandung

Gamal Suwantoro, (1997). Dasar-dasar Pariwisata: ANDI OFFSET, Yogyakarta.

Hadi, S. P. 2005. Dimensi Lingkungan Perencanaan Pembangunan. Gadjah Mada University Press. Yogyakarta.

Hendro Prastowo, dkk. 1982. Mengenal Hutan Jawa Tengah. emarang, Perum Perhutani Unit 1 Jawa Tengah

http://www.hariankomentar.com/arsip/arsip 2007/ags 04/hl003.html

Indriyanto. 2006. Ekologi Hutan. Penerbit Bumi Aksara. Jakarta

Ismal, Gazali. 1995. Ekologi Tumbuhan dan Tanaman Pertanian. Padang. Angkasa Raya Padang

James J. Spillane. 1993. Ekonomi Pariwisata: Sejarah dan Prospeknya. Kanisius, Yogyakarta

Mortensen, E dan E.T. Bullard. 1964. Hand Book of Tropical and Subtropical Horticulture Dept. Of State Agency for Int. Development Communication Resources Division Publication and Technical Services Branch Washington D.C.

Salah Wahab. 1976. Manajemen Kepariwisataan Terjemahan Frans Gromang, PT Pradnya Paramita Jakarta.

Siswanto, Joko. 2001. "Kajian Permukiman Prasejarah di Pulau Karakelang. Kabupaten Sangihe - Talaud, Provinsi Sulawesi Utara." Laporan Penelitian Arkeologi, Kementerian Negara Kebudayaan dan Pariwisata. Balai Arkeologi Manado

Tanudirjo Daud Aris. 2001. Islands in Between. Prehistory of the Northeastern Indonesian Archipelago. (Volume 1). A thesis submitted for the degree of Doctor of Philosophy of The Australian National University. December 2001,

Thufail, Fadjar Ibnu. 1993. Adaptasi Lingkungan dan Perkembangan Kebudayaan Talaud. Masyarakat Indonesia. Tahun XX, No. 1. Pusat Dokumentasi dan Informasi IImiah. PDII - LIPI.

Tim Teknis Direktorat Jenderal Penataan Ruang 2005. Rancangan Peraturan Presiden Republik Indonesia Tentang Rencana Tata Ruang (RTR) Pulau Sulawesi. Badan Koordinasi Tata Ruang Nasional. Departemen Pekerjaan Umum

Wahyono, Ary; Fadjar Ibnu Thufail, dan Thung Julan. 1992. Masyarakat Nelayan Kelurahan Beo, Kabupaten Sangihe Talaud, Sulawesi Utara dalam Laporan Penelitian Aspek-aspek Sosial Budaya Masyaralat Maritim Indonesia Bagian Timur. Jakarta: PMB-LIPI 
